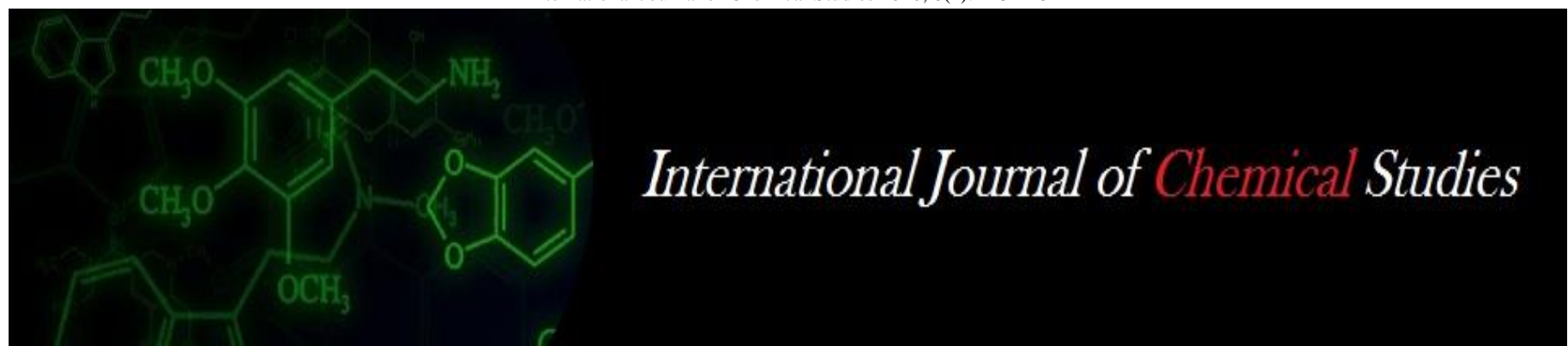

P-ISSN: 2349-8528

E-ISSN: 2321-4902

www.chemijournal.com

IJCS 2020; 8(2): 223-228

(C) 2020 IJCS

Received: 01-01-2020

Accepted: 03-02-2020

\section{Kumari Namrata}

Department of Agril.

Biochemistry, Faculty of

Agriculture, Bidhan Chandra

Krishi Vishwavidyalaya,

Mohanpur, Nadia, West Bengal,

India

\section{Jhuma Datta}

Department of Agril.

Biochemistry, Faculty of

Agriculture, Bidhan Chandra

Krishi Vishwavidyalaya,

Mohanpur, Nadia, West Bengal,

India

\section{Rajeev Kumar}

Department of Agril.

Biochemistry, Faculty of

Agriculture, Bidhan Chandra

Krishi Vishwavidyalaya,

Mohanpur, Nadia, West Bengal

A Chakravarty

Department of Agril.

Biochemistry, Faculty of

Agriculture, Bidhan Chandra

Krishi Vishwavidyalaya,

Mohanpur, Nadia, West Bengal, India

Srikumar Pal

Department of Agril.

Biochemistry, Faculty of

Agriculture, Bidhan Chandra

Krishi Vishwavidyalaya,

Mohanpur, Nadia, West Bengal,

India

\section{Herbicide induced changes in nutrient and antinutrient content during mung bean (Vigna radiata $\mathrm{L}$.) seed development}

\author{
Kumari Namrata, Jhuma Datta, Rajeev Kumar, A Chakravarty and \\ Srikumar Pal
}

DOI: https://doi.org/10.22271/chemi.2020.v8.i2d.8772

\begin{abstract}
The present study reports the influence of two herbicides viz. Pendimethalin and imazethapyr on the changes in sugar, starch, protein, trypsin inhibitory activity (TIA), phenol content and antioxidant activity at the different stages of mung bean seed development. Each of the herbicides was applied at their recommended field dose (RFD) and double of the RFD (dRFD). Sugar content in seed was adversely affected by these herbicides, while starch and protein content were significantly increased at RFD of pendimethalin and imazethapyr respectively. Imazethapyr at dRFD registered lowest TIA level. Phenol content and antioxidant activity measured usingdiphenyl-2-picrylhydrazyl (DPPH), Azino-bis (3ethylbenzothiazoline-6-sulphonic acid $\left(\mathrm{ABTS}^{+}\right)$and Ferric reducing antioxidant power (FRAP) assay, enhanced by pendimethalin treatment at RFD. Antioxidant activity under DPPH, ABTS and FRAP assays showed significant positive relation with phenol content $(r=0.99,0.96$ and 0.94 respectively) between them. DPPH assay produced higher absolute value for antioxidant activity as compared to other assay.
\end{abstract}

Keywords: Mung bean, herbicides, nutrient components, antinutrients (trypsin inhibitor)

\section{Introduction}

Mung bean (Vigna radiata L.), belonging to the family Fabaceae, is one of the most important short duration pulse crops grown in almost all parts in India. It occupies a unique position in human diet due to its highprotein content varying between22 and28\% with 6065\% carbohydrate, 11.5\% fat and3.5-4.5\% fibres (Abdel-Lateef, 1996 and Mosalem, 1999) ${ }^{[1,}$ 19]. This crop is also rich in essential amino acids, lysine, comparable to that of soybean and kidney bean (Abd El-Sattar et al., 2000) ${ }^{[2]}$. In addition, mung bean is endowed with a variety of phenolic compounds including phenolic acids and flavonoids, which occur in both free and bound forms. Shi et al., (2016) ${ }^{[31]}$ identified fourbound phenolic acids viz. syringic, caffeic, pcoumaric, and ferulic acids and two free phenolic acids (caffeic and ferulic acids) in different mung bean cultivars of China. They also observed a significant positive correlation betweentotal phenolic acids and total flavonoid content and antioxidant activity based on scavenging of $\mathrm{ABTS}^{+}$free-radical. Moreover, mung bean has received much attention due to anti-angiotensin I-converting enzyme, antitumor, antioxidant, anti-diabetic, and antimelanocyte components (Li, et al., 2005; Soucek et al., 2006; Randhir et al., 2007 and Yao et al., 2008) ${ }^{[32,25,38]}$. Sprouted seeds of mung bean have also been recognized as rich source of vitamin C (Ghanem \& Abbas, 2009) ${ }^{[11]}$. Mung bean, though traditionally known as a functional food, but its protein digestibility is prevented by the presence of trypsin inhibitor (Guillomen et al., 2008) [13]. This antinutritional component of food poses a serious threat, when consumed uncooked (Bradbury and Holloway, 1988) ${ }^{[7]}$ and thusplay a defensive role against insect pests (Wati et al., 2009) ${ }^{[37]}$.

India ranks first in mung bean production in the world amounting to 1.82 million tons from an area of 3.55 million hectares (India Stat, 2013). Among several factors, a number of broad and narrow leaf weeds has become a major constraint restricting its production and the yield losses has been estimated to be about $40 \%$ depending on the species and density of weeds (Tomar et $a l ., 2011)^{[33]}$.
Corresponding Author: Kumari Namrata

Department of Agril.

Biochemistry, Faculty of

Agriculture, Bidhan Chandra

Krishi Viswavidyalaya,

Mohanpur, Nadia, West Bengal, India 
Therefore, modern agriculture relies on the application of the herbicides to control weeds. Thus in the cultivation schedule of mung bean, the use of herbicides viz. pendimethalin, quizalofop, fenoxaprop and imazethapyr has been recommended by All India Network Programme (AINP) on pulses. The adverse effect of herbicides on weed population results from selective impairment of a particular metabolic pathway as well as differential rate of chemical, biochemical and photochemical transformation affecting persistence of this chemical. Accordingly, pendimethalin, a member of dinitroaniline class, exerts its toxic influence on weeds by inhibiting microtubule assembly leading to disruption of cell division (Vaughn and Lehnen, 1991) ${ }^{[34]}$, while imazethapyr, a member of imidazolinones class, inhibits acetolactate synthase (ALS) and thus block the synthesis of branched chain amino acids such as leucine, isoleucine and valine (LaRossa \& Scholos, 1984) ${ }^{[15]}$. In recent years, it has been documented that herbicides, in addition to their recognized role, can also affect the other metabolic pathways of plant viz. carbon, nitrogen and phenol metabolism. For example, imazethapyr has been reported to adversely affect the activities of Rubisco, nitrate reductase, nitrite reductase, glutamine synthetase, glutamate 2-oxoglutarate amino transferase (Miflin et al., 1990, Lea et al., 1990 \& Goodwill et al., 1983) [17, 16, 12], while pendimethalin to modulate the phenylalanine ammonia lyase activity. Thus, herbicides with their profound influence on the enzymes of phenol, carbohydrate and nitrogenmetabolismare likely to modulate the content of the end products of these pathways. Thus, it left unanswered the question whether herbicide-induced changes in the chemical composition of plant influence human health. With these background information, an attempt has been made in present study to find out the impact of two herbicides viz. pendimethalin, and imazethapyr, each applied at their RFD and dRFD, on the changes in contents of phenol (total and free phenol), carbohydrate (starch and sugar) and protein including trypsin inhibitory activity during the period of seed development of mung bean. In addition, antioxidant activities of total phenol extracts under different systems of assay viz. DPPH, ABTS and FRAP havealso been examined in order to obtain the most viable treatment which can enhance the nutritional property of mung bean without any risk arising from herbicide residues.

\section{Material and methods \\ Plant material and chemicals}

Mung bean was raised at University research farm, Bidhan Chandra Krishi Vishwavidyalaya, Mohanpur, Nadia, West Bengal following the usual agronomic practices. The seeds of mung bean were surface sterilized with $0.5 \%$ of $\mathrm{HgCl}_{2}(\mathrm{w} / \mathrm{v})$ for 10 minutes followed by washing with distilled water thrice to remove the traces of $\mathrm{HgCl}_{2}$.Pendimethalin @ $1.0 \mathrm{~kg}$ ai/ha (RFD) and $2.0 \mathrm{~kg}$ ai/ha (dRFD) were applied as pre-emergent herbicide before sowing, while imazethapyr @ $25.0 \mathrm{~g}$ ai/ha. (RFD) and $50.0 \mathrm{~g}$ ai/ha (dRFD) were applied as postemergent herbicide on 20 and 40 days after sowing. These four treatments along with an untreated control were arranged in a randomized block design (RBD) with three replications of each treatment.

\section{Sampling}

Seed samples of mung bean were collected from each treatment replications periodically at 10, 15, 20, 25 and 30 days after fruit setting (DAFS). Seed samples were oven dried at $40{ }^{\circ} \mathrm{C}$ till constant weight and ground using an electric grinder. The dried sample was then subjected to chemical analysis.

\section{Chemical}

ABTS was procured from Fluka Chemical Co. and Trolox from Sigma Aldrich Chemical Co. Other reagents were of analytical grade.

\section{Chemical analysis}

Analysis of total sugar and starch

Sugar was extracted using $15 \mathrm{ml}$ of $80 \%$ anhydrous alcohol by boiling $0.1 \mathrm{~g}$ dry powdered sample for $30 \mathrm{~min}$ at $80^{\circ} \mathrm{C}$ followed by centrifugation at $10,000 \mathrm{rpm}$ for 30 minute. The extraction was repeated thrice. The extract after evaporating off in a water bath was made to $50 \mathrm{ml}$ with water, which was used for sugar analysis. Theresidue, after drying at $80^{\circ} \mathrm{C}$, was treated with $52 \%$ perchloric acid for starch extraction and the process was repeated thrice. The sugar and starch content was measured using anthrone reagent (Sen et al., 2005) ${ }^{[30]}$.

\section{Estimation of Crude Protein}

The crude protein content was determined using Kjeldahl method (Sadasivam and Manikam, 2011) [28] of nitrogen analysis. Briefly, $0.5 \mathrm{~g}$ dried samples, $10 \mathrm{~g}$ of digestion mixture $\left(\mathrm{K}_{2} \mathrm{SO}_{4}: \mathrm{FeSO}_{4}: \mathrm{CuSO}_{4} .5 \mathrm{H}_{2} \mathrm{O}\right.$ in 10:1:1 ratio) and $15 \mathrm{ml}$ of 0.1 $\mathrm{N}$ concentrated Sulphuric acid were taken in the Kjeldahl flask and heated till complete digestion (2hr), which turned into green colour. The cooled solution was then added with 15 $\mathrm{ml}$ water and $70 \mathrm{ml} \mathrm{40 \%} \mathrm{NaOH}$ was added and distilled to obtain volatile ammonia in a $250 \mathrm{ml}$ conical flask containing $25 \mathrm{ml}$ of $4 \%$ boric acid. The content of ammonia was measured by titration against $1 \%$ sulphuric acid, which changed the colour from green to pink at the end point. The nitrogen content in the sample was calculated by the following relation

$\%$ of nitrogen $=(\mathrm{T}-\mathrm{B}) \times 1.4 \times \mathrm{N} \mathrm{HCl} / \mathrm{W}$

Where, $\mathrm{T}$ and $\mathrm{B}$ represents quantity of $\mathrm{H}_{2} \mathrm{SO}_{4}$ used for titration of test and blank sample, $\mathrm{N}$ for strength of $\mathrm{H}_{2} \mathrm{SO}_{4}$ and $\mathrm{W}$ for weight of the sample taken.

\section{Trypsin inhibitor (EC 3.4.21.4) analysis}

$0.1 \mathrm{~g}$ seed sample was homogenized with $10 \mathrm{ml}$ Tris $-\mathrm{CaCl}_{2}$ buffer solution (0.04 M Tris, $0.01 \mathrm{M} \mathrm{CaCl}_{2}, \mathrm{pH}$ 8.1). The homogenate was allowed to stand for 5 minutes before centrifugation at $10,000 \mathrm{rpm}$ at $5^{\circ} \mathrm{C}$ (Bradburry and Hammer, 1990) ${ }^{[6]}$. A serial dilution of aliquot was treated with $20 \mu \mathrm{l}$ of trypsin $\left(1 \mathrm{mg} \mathrm{mL}^{-1}\right)$ at $37^{\circ} \mathrm{C}$ for $15 \mathrm{~min}$, following the method of Kakade et al. (1974). Then, 40 $\mu 1$ (from the stock solution of $10 \mathrm{mg} \mathrm{mL}-1$ in Dimethyl Sulfoxide) BApNA (N- $\alpha$ benzoal-DL-Arginine p-nitro anilide) was added to the assay solution and the mixture was again incubated at $37^{\circ} \mathrm{C}$ for 30 min. Reaction was stopped by adding $0.5 \mathrm{ml}$ of $30 \%$ of glacial acetic acid and the absorbance of the reaction mixture was measured at $410 \mathrm{~nm}$ against a blank without substrate and a blank containing crude extract without BApNA in order to subtract the absorbance of the crude extract. Trypsin inhibitory activity (TIA) was determined by the difference between the enzyme activity in the absence and in the presence of inhibitor. One TIU is defined as a decrease in $\mathrm{A}_{410}$ by 0.01 in 10 minutes. TIA is expressed in the units of trypsin inhibited (TIU) per mg of dry matter of the sample.

\section{Total Phenol}

The total phenol content in mung bean seed was extracted following the method described by (Vinson et al., 1998). 
Briefly, 0.1g dried powder of seed was extracted with $15 \mathrm{ml}$ of $1.2 \mathrm{~N} \mathrm{HCl}$ in $50 \%$ aqueous methanol by shaking in water bath at $90^{\circ} \mathrm{C}$ for 2 hours. The extract was centrifuged at $10,000 \mathrm{rpm}$ for 30 minutes. The supernatant was evaporated to dryness and diluted to a suitable volume, which was analyzed using Folin Ciocalteau Reagent (FCR). The absorbance was recorded at $650 \mathrm{~nm}$ and the phenol content was expressed in mg of Gallic Acid Equivalent (mg GAE) per gram dry matter (/g DM).

\section{Antioxidant activity}

The antioxidant activity of phenol extract was measured using neutral DPPH and $\mathrm{ABTS}^{+}$radical as per method described by Braca et al., (2001) [5] and Ozgen et al., (2006) [22] respectively. On the other hand, Ferric reducing antioxidant power (FRAP), which is based on the reduction Fe (III) to $\mathrm{Fe}$ (II) was determined according to method adopted by Benzie and Strain (1996) ${ }^{[4]}$. In each assay technique, $150 \mu \mathrm{l}$ of phenol extract was mixed with $2850 \mu \mathrm{l}$ of DPPH $(0.004 \%)$ solution / $\mathrm{ABTS}^{+}$solution/ FRAP reagent. The mixture was kept 30 minutes in the dark, after which the change in absorbance with or without extract was read at517, 734 and $593 \mathrm{~nm}$ in DPPH, ABTS and FRAP assay respectively. For each assay techniques employed in the present study, the antioxidant activity was measured using a calibration curve of trolox and expressed as mg TE/g DM.

\section{Stastical analysis}

All data were subjected to analysis statistically by ANOVA of a RBD design, to determine differences among means. Statistical analyses were done using SPSS Professional Statistics ver. 7.5 (SPSS Inc., Irvine, California).

\section{Results and Discussion \\ Sugar and starch content of mung bean:}

The changes in sugar and starch content at different stages of seed development in response to different treatments are presented in Table 1. Both these nutrient components showed differential response throughout the experimental period according to the nature and dose of herbicide applied. Mean sugar and starch content in different treatments over different sampling days varied significantly. However, mean sugar content in seeds that received herbicide treatment regardless of their nature and dose decreased below control. However, starch content increased over control with pendimethalin treatment at RFD. Moreover, higher application rate of each of these herbicides caused a reduction both in sugar and starch content than their corresponding lower dose. The mean sugar and starch content at different sampling days over different treatments showed significant differences. Sugar and starch content increased progressively till it reached maximum on 20 and 25DAFS. Finally both these components declined at harvest. The similar trend was also noticed with all the herbicide treatments for sugar except untreated control, which significantly increased throughout the experimental period.

Table 1: Changes in sugar and starch content (\%) at DAFS in the mung bean (Vigna radiata L.)

\begin{tabular}{|c|c|c|c|c|c|c|c|c|c|c|c|c|}
\hline \multicolumn{7}{|c|}{ Starch at Different DAFS } & \multicolumn{6}{|c|}{ Sugar (\%) at Different DAFS } \\
\hline Treatments (ai g ha-1) & 10 & 15 & 20 & 25 & 30 & Mean & 10 & 15 & 20 & 25 & 30 & Mean \\
\hline Untreated Control (0) & $49.19^{\mathrm{B} \delta}$ & $45.14^{\mathrm{D} \varepsilon}$ & $56.80^{\mathrm{A} \gamma}$ & $65.88^{\mathrm{B} \alpha}$ & $62.95^{\mathrm{A} \beta}$ & $55.99^{\mathrm{B}}$ & $7.21^{\mathrm{A} \gamma}$ & $7.48^{\mathrm{A} \gamma}$ & $7.25^{\mathrm{B} \Gamma}$ & $8.24^{\mathrm{A} \beta}$ & $8.84^{\mathrm{A} \alpha}$ & $7.81^{\mathrm{A}}$ \\
\hline Pendimethalin 1000 & $50.89^{\mathrm{A} \varepsilon}$ & $57.72^{\mathrm{A} \gamma}$ & $53.32^{\mathrm{B} \delta}$ & $66.95^{\mathrm{A \alpha}}$ & $58.54^{\mathrm{B} \beta}$ & $57.48^{\mathrm{A}}$ & $4.82^{\mathrm{B} \varepsilon}$ & $7.12^{\mathrm{B} \beta}$ & $7.84^{\mathrm{A} \alpha}$ & $5.7^{\mathrm{CD} \delta}$ & $6.57^{\mathrm{B} \gamma}$ & $6.41^{\mathrm{B}}$ \\
\hline Pendimethalin 2000 & $46.39^{\mathrm{C} \delta}$ & $44.01^{\mathrm{E \varepsilon}}$ & $49.87^{\mathrm{D} \gamma}$ & $65.82^{\mathrm{B} \alpha}$ & $55.17^{\mathrm{C} \beta}$ & $52.25^{\mathrm{D}}$ & $4.11^{\mathrm{C} \varepsilon}$ & $6.97^{\mathrm{B} \beta}$ & $7.28^{\mathrm{B} \alpha}$ & $5.87^{\mathrm{BC} \gamma}$ & $5.54^{\mathrm{C} \delta}$ & $5.95^{\mathrm{C}}$ \\
\hline Imazethapyr 25.0 & $51.04^{\mathrm{A} \delta}$ & $56.70^{\mathrm{B} \beta}$ & $51.21^{\mathrm{C} \delta}$ & $62.16^{\mathrm{Ca}}$ & $54.92^{\mathrm{C} \gamma}$ & $55.21^{\mathrm{C}}$ & $3.76^{\mathrm{D} \delta}$ & $6.46^{\mathrm{C} \beta}$ & $6.77^{\mathrm{CA}}$ & $6.20^{\mathrm{B} \beta}$ & $5.62^{\mathrm{C} \gamma}$ & $5.77^{\mathrm{D}}$ \\
\hline Imazethapyr50.0 & $47.09^{\mathrm{C} \delta}$ & $49.89^{\mathrm{C} \gamma}$ & $45.25^{\mathrm{E} \varepsilon}$ & $57.43^{\mathrm{D} \alpha}$ & $51.17^{\mathrm{D} \beta}$ & $50.16^{\mathrm{E}}$ & $3.38^{\mathrm{E} \delta}$ & $5.16^{\mathrm{D} \beta \gamma}$ & $7.74^{\mathrm{A} \alpha}$ & $5.43^{\mathrm{D} \beta}$ & $5.04^{\mathrm{D} \gamma}$ & $5.35^{\mathrm{E}}$ \\
\hline Total Mean & $48.92^{\mathrm{A}}$ & $50.69^{\mathrm{D}}$ & $51.29^{\mathrm{C}}$ & $63.65^{\mathrm{A}}$ & $56.55^{\mathrm{B}}$ & & $4.66^{\mathrm{D}}$ & $6.64^{\mathrm{B}}$ & $7.38^{\mathrm{A}}$ & $6.29^{C}$ & $6.32^{\mathrm{C}}$ & \\
\hline $\operatorname{LSD}(p=0.05)$ & \multicolumn{6}{|c|}{0.54} & \\
\hline
\end{tabular}

Total protein content and trypsin inhibitory activity of mung bean:

The results relating to proteinand TIA level in mung bean seed at different DAFS are summarized in Table2. Similar to sugar and starch content, protein content and TIA level showed a differential response depending on herbicides and their dosed applied. Mean protein content over different sampling days was significantly higher over control in imazethapyr treatment at RFD, which was comparable to that of pendimethalin treatment at RFD. Among the treatments, pendimethalin at dRFD produced the lowest protein. The adverse effect of herbicides on protein content was more pronounced with application of pendimethalin at dRFD. The protein content in mung bean (18.54 to $19.60 \%$ ) obtained in the present study was somewhat lower as compared to earlier report (Ofuya et al., 2005) ${ }^{[21]}$, which can be ascribed to differences in genotype and growing condition. Similar to starch content, the mean protein content at different sampling days over treatment increased significantly till 20 DAFS with subsequent decline at harvest. Similar trend was also noticed with individual treatments except pendimethalin at RFD, where highest protein content was observed on 15 DAFS.
The mean TIA level over different sampling days was significantly higher than that of untreated control in pendimethalin treatment at RFD and dRFD. With imazethapyr treatment, TIA level declined below control at dRFD. The corresponding TIA level in untreated control and imazethapyr treatment at RFD. The observed TIA level ranging from 0.620.73 was comparable to the report of Rasha et al., (2011) ${ }^{[26]}$. However, Wang et al. (1998) ${ }^{[36]}$ observed a wide variation in TIA levels ranging between 2.22 and $7.66 \mathrm{TIU} / \mathrm{mg} \mathrm{DM}$ ) in field pea, which appears to result from differences in genotype and environment with their contribution of $55.3 \%$ and $17.7 \%$ of total variation respectively. The increase in TIA over control due to pendimethalin treatment seems to be linked to herbicide-induced oxidative stress (Mondy and Chandra, 1979; Ryan, 1973) ${ }^{[18,27]}$. The mean TIA level at different sampling days over treatment reached maximum on 25 DAFS, which was also discernible with individual treatments. Such trend in TIA level was also reported during the seed development in kidney bean (Alizadeh et al., 2012) [3]. 
Table 2: Changes in protein content (\%) and TIA level (TIU/mg DM) at DAFS

\begin{tabular}{|c|c|c|c|c|c|c|c|c|c|c|c|c|}
\hline \multicolumn{7}{|c|}{ protein content at Different DAFS } & \multicolumn{6}{|c|}{ TIA level at Different DAFS } \\
\hline Treatments (ai $\mathrm{g} \mathrm{ha}^{-1}$ ) & 10 & 15 & 20 & 25 & 30 & Mean & 10 & 15 & 20 & 25 & 30 & Mean \\
\hline Untreated Control (0) & $17.41^{\mathrm{D} \delta}$ & $19.87^{\mathrm{B} \beta}$ & $20.85^{\mathrm{AB} \alpha}$ & $19.87^{\mathrm{A} \beta}$ & $18.36^{\mathrm{A} \gamma}$ & $19.27^{\mathrm{B}}$ & $0.53^{\mathrm{Ca}}$ & $0.56^{\mathrm{A} \gamma}$ & $0.69^{\mathrm{C} \beta}$ & $0.86^{\mathrm{A} \gamma}$ & $0.53^{\mathrm{B} \delta}$ & $0.63^{\mathrm{C}}$ \\
\hline Pendimethalin 1000 & $18.86^{\mathrm{B} \gamma}$ & $21.09^{\mathrm{A} \alpha}$ & $20.45^{\mathrm{BC} \beta}$ & $18.88^{\mathrm{B} \gamma}$ & $17.67^{\mathrm{B} \delta}$ & $19.39^{\mathrm{AB}}$ & $0.71^{\mathrm{B} \alpha}$ & $0.59^{\mathrm{A} \beta}$ & $0.74^{\mathrm{B} \gamma}$ & $0.85^{\mathrm{A} \delta}$ & $0.62^{\mathrm{A} \varepsilon}$ & $0.70^{\mathrm{B}}$ \\
\hline Pendimethalin 2000 & $18.09^{\mathrm{C} \gamma}$ & $19.09^{\mathrm{C} \beta}$ & $20.15^{\mathrm{C} \alpha}$ & $18.22^{\mathrm{C} \gamma}$ & $17.15^{\mathrm{C} \delta}$ & $18.54^{\mathrm{D}}$ & $0.76^{\mathrm{A} \alpha}$ & $0.59^{\mathrm{A} \beta}$ & $0.83^{\mathrm{A} \gamma}$ & $0.86^{\mathrm{A} \delta}$ & $0.61^{\mathrm{A} \varepsilon}$ & $0.73^{\mathrm{A}}$ \\
\hline Imazethapyr 25.0 & $19.67^{\mathrm{AB} \gamma}$ & $20.63^{\mathrm{AB} \alpha \beta}$ & $21.23^{\mathrm{A} \alpha}$ & $18.96^{\mathrm{B} \gamma}$ & $17.51^{\mathrm{BC} \delta}$ & $19.60^{\mathrm{A}}$ & $0.68^{\mathrm{B} \alpha}$ & $0.57^{\mathrm{A} \beta}$ & $0.61^{\mathrm{D} \gamma}$ & $0.81^{\mathrm{B} \delta}$ & $0.55^{\mathrm{B} \varepsilon}$ & $0.64^{\mathrm{C}}$ \\
\hline Imazethapyr 50.0 & $18.32^{\mathrm{BC} \gamma}$ & $19.07^{\mathrm{C} \beta}$ & $20.00^{\mathrm{C} \alpha}$ & $19.01^{\mathrm{B} \beta}$ & $18.26^{\mathrm{A} \gamma}$ & $18.93^{\mathrm{C}}$ & $0.66^{\mathrm{E} \delta}$ & $0.51^{\mathrm{B} \beta}$ & $0.60^{\mathrm{D} \beta}$ & $0.80^{\mathrm{B} \gamma}$ & $0.51^{\mathrm{B} \delta}$ & $0.62^{\mathrm{D}}$ \\
\hline Total Mean & $18.47^{\mathrm{D}}$ & $19.95^{\mathrm{B}}$ & $20.54^{\mathrm{A}}$ & $18.99^{\mathrm{C}}$ & $17.79^{\mathrm{E}}$ & & $0.67^{\mathrm{C}}$ & $0.56^{\mathrm{D}}$ & $0.69^{\mathrm{B}}$ & $0.84^{\mathrm{A}}$ & $0.56^{\mathrm{D}}$ & \\
\hline $\operatorname{LSD}(\mathrm{p}=0.05)$ & \multicolumn{6}{|c|}{0.54} & \multicolumn{6}{|c|}{0.27} \\
\hline
\end{tabular}

Same English Letter followed by mean are not significantly different with in a column and same Greek letter followed by mean are not significantly different within a row.

\section{Total phenol content and antioxidant activity of mung bean}

Total phenol content and antioxidant activity of phenol extract are presented in Table 3 and 4 . The results indicated that mean phenol content in different treatments over different sampling days varied significantly. However, all the treatments except pendimethalin at RFD, produced mean total phenol, which were lower than that of control. The decrease in total phenol content was more pronounced with higher application rate for each of these herbicides. The range in total phenol recorded in this study compared well with the report of Parikh and Patel (2018) ${ }^{[23]}$. Furthermore, seed samples collected 10 DAFS registered highest total phenol, which varied depending on the nature of the herbicides. Finally, it decreased gradually throughout the experimental period. Thus, herbicide induced changes in phenol content supports the differential modulation of phenol metabolism (Scarponi et al., 1992, Nemat Alla \& Younis, 1995) ${ }^{[29,20] .}$

The mean antioxidant activity in different treatments over different sampling days differed significantly depending on treatments as well as assay techniques employed. In all assays, the mean antioxidant activity of seed samples response to application of pendimethalin at RFD was significantly higher than that of control samples, while other treatments recorded mean antioxidant activity, which is significantly lower than control and the activity was lowest with imazethapyr treatment at dRFD. The similarity in rank order of antioxidant activity among treatments under DPPH,
ABTS and FRAP assay was in well agreement with the report of Wang et al., (1998) [36]. It was further noticed that the treatment, which produced greater phenol displayed higher antioxidant activity, which was further evidenced by the significant positive relation between total phenol and antioxidant activity $(r=0.99,0.96$ and 0.94 in DPPH, ABTS and FRAP assay respectively Moreover, a positive relation between antioxidant assay methods $(\mathrm{r}=0.95,0.94$ and 0.99 between DPPH and ABTS, DPPH and FRAP and ABTS and FRAP respectively) was also discernible in the present study. The mean antioxidant activity regardless of assay techniques used, reached maximum at the initial day of observation followed by gradual decline throughout the experimental period. The higher antioxidant activity on 10 DAFS as noticed in the present study is supported by the observation of Garcia et al., (2019) ${ }^{[10]}$, who reported that fruits during its physiological development registered higher total phenol and antioxidant activity on 10 days after anthesis. Several lines of evidence indicate that antioxidant activity of a sample is related to phenolic compounds present in the sample (Fidrianny et al.,2015) ${ }^{[9]}$. The absolute value of antioxidant activity under DPPH assay was found to be higher followed by FRAP and ABTS assays indicating that phenolic compounds participate in antioxidant reaction involving hydrogen atom transfer (HAT) rather than single electron transfer (SET) mechanism and HAT based antioxidant reaction is more effective for neutral rather than radical cation.

Table 3: Changes in Antioxidant activity under DPPH and ABTS (mgTE/g DM) assay at DAFS

\begin{tabular}{|c|c|c|c|c|c|c|c|c|c|c|c|c|}
\hline \multicolumn{7}{|c|}{ DPPH assay at Different DAFS } & \multicolumn{6}{|c|}{ ABTS assay at Different DAFS } \\
\hline Treatments (ai g ha-1) & 10 & 15 & 20 & 25 & 30 & Mean & 10 & 15 & 20 & 25 & 30 & Mean \\
\hline Untreated Control (0) & $47.65^{\mathrm{C} \alpha}$ & $41.85^{\mathrm{A} \beta}$ & $40.00^{\mathrm{A} \gamma}$ & $36.30^{\mathrm{A} \delta}$ & $32.92^{\mathrm{A} \varepsilon}$ & $39.75^{\mathrm{B}}$ & $4.89^{\mathrm{C} \alpha}$ & $4.50^{\mathrm{BB}}$ & $4.09^{\mathrm{B} \gamma}$ & $3.65^{\mathrm{A} \delta}$ & $3.28^{\mathrm{B} \varepsilon}$ & $4.08^{\mathrm{B}}$ \\
\hline Pendimethalin 1000 & $53.59^{\mathrm{A} \alpha}$ & $40.35^{\mathrm{B} \beta}$ & $39.73^{\mathrm{A} \gamma}$ & $35.88^{\mathrm{A} \delta}$ & $34.15^{\mathrm{A} \varepsilon}$ & $40.74^{\mathrm{A}}$ & $5.47^{\mathrm{AA}}$ & $4.85^{\mathrm{AB}}$ & $4.53^{\mathrm{A} \gamma}$ & $3.81^{\mathrm{A} \delta}$ & $3.53^{\mathrm{A} \delta}$ & $4.44^{\mathrm{A}}$ \\
\hline Pendimethalin 2000 & $46.18^{\mathrm{D} \alpha}$ & $39.41^{\mathrm{C} \beta}$ & $32.45^{\mathrm{B} \gamma}$ & $31.10^{\mathrm{B} \gamma}$ & $29.17^{\mathrm{B} \delta}$ & $35.66^{\mathrm{C}}$ & $4.97^{\mathrm{C} \alpha}$ & $4.58^{\mathrm{BB}}$ & $3.44^{\mathrm{C} \gamma}$ & $3.29^{\mathrm{B} \gamma}$ & $3.01^{\mathrm{C} \delta}$ & $3.86^{\mathrm{C}}$ \\
\hline Imazethapyr 25.0 & $50.94^{\mathrm{B} \alpha}$ & $38.59^{\mathrm{D} \beta}$ & $30.19^{\mathrm{C} \gamma}$ & $30.15^{\mathrm{C} \gamma}$ & $29.86^{\mathrm{B \Gamma}}$ & $35.95^{\mathrm{C}}$ & $5.09^{\mathrm{B} \alpha}$ & $4.64^{\mathrm{AB} \beta}$ & $3.33^{\mathrm{C} \gamma}$ & $3.00^{\mathrm{C} \delta}$ & $2.75^{\mathrm{D} \varepsilon}$ & $3.76^{\mathrm{C}}$ \\
\hline Imazethapyr 50.0 & $42.98^{\mathrm{E} \alpha}$ & $32.05^{\mathrm{E} \beta}$ & $29.97^{\mathrm{C} \gamma}$ & $29.75^{\mathrm{C} \gamma}$ & $29.09^{\mathrm{B} \delta}$ & $32.77^{\mathrm{D}}$ & $4.79^{\mathrm{CA}}$ & $3.13^{\mathrm{CB}}$ & $2.77^{\mathrm{D} \gamma}$ & $2.49^{\mathrm{D} \delta}$ & $2.04^{\mathrm{E} \varepsilon}$ & $3.04^{\mathrm{D}}$ \\
\hline Total Mean & $48.27^{\mathrm{A}}$ & $38.45^{\mathrm{B}}$ & $34.47^{\mathrm{C}}$ & $32.64^{\mathrm{D}}$ & $31.04^{\mathrm{E}}$ & & $5.04^{\mathrm{A}}$ & $4.34^{\mathrm{B}}$ & $3.63^{\mathrm{C}}$ & $3.25^{\mathrm{D}}$ & $2.92^{\mathrm{E}}$ & \\
\hline LSD $(p=0.05)$ & \multicolumn{6}{|c|}{0.74} & \multicolumn{6}{|c|}{0.22} \\
\hline
\end{tabular}

Table 4: Changes in Antioxidant activity using FRAP (mgTE/g DM) assay and phenol content (mg GAE/g DM) at different days after fruit setting (DAFS)

\begin{tabular}{|c|c|c|c|c|c|c|c|c|c|c|c|c|}
\hline \multicolumn{7}{|c|}{ FRA Passayat Different DAFS } & \multicolumn{6}{|c|}{ Phenol content at Different DAFS } \\
\hline Treatments (ai g ha-1) & 10 & 15 & 20 & 25 & 30 & Mean & 10 & 15 & 20 & 25 & 30 & Mean \\
\hline Untreated Control(0) & $10.98^{\mathrm{C} \alpha}$ & $10.61^{\mathrm{B} \beta}$ & $10.30^{\mathrm{B} \gamma}$ & $9.93^{\mathrm{B} \Delta}$ & $9.45^{\mathrm{B} \varepsilon}$ & $10.25^{\mathrm{B}}$ & $47.41^{\mathrm{C} \alpha}$ & $42.73^{\mathrm{A} \beta}$ & $38.73^{\mathrm{A} \gamma}$ & $35.04^{\mathrm{A} \delta}$ & $31.70^{\mathrm{B} \varepsilon}$ & $39.12^{\mathrm{A}}$ \\
\hline Pendimethalin 1000 & $11.42^{\mathrm{A} \alpha}$ & $11.00^{\mathrm{A} \beta}$ & $10.61^{\mathrm{A} \gamma}$ & $10.33^{\mathrm{A} \delta}$ & $9.95^{\mathrm{A} \varepsilon}$ & $10.67^{\mathrm{A}}$ & $53.13^{\mathrm{A} \alpha}$ & $41.96^{\mathrm{B} \beta}$ & $38.20^{\mathrm{A} \gamma}$ & $34.69^{\mathrm{B} \delta}$ & $33.02^{\mathrm{A} \varepsilon}$ & $40.20^{\mathrm{B}}$ \\
\hline Pendimethalin 2000 & $11.15^{\mathrm{B} \alpha}$ & $10.06^{\mathrm{C} \beta}$ & $10.07^{\mathrm{C} \beta}$ & $9.65^{\mathrm{C \Gamma}}$ & $9.01^{\mathrm{C} \delta}$ & $9.99^{\mathrm{C}}$ & $47.97^{\mathrm{C} \alpha}$ & $38.99^{\mathrm{C \beta}}$ & $31.61^{\mathrm{B} \gamma}$ & $30.44^{\mathrm{C} \delta}$ & $29.69^{\mathrm{C \varepsilon}}$ & $35.74^{\mathrm{C}}$ \\
\hline Imazethapyr 25.0 & $11.33^{\mathrm{A} \alpha}$ & $10.66^{\mathrm{B} \beta}$ & $9.74^{\mathrm{D} \Gamma}$ & $9.46^{\mathrm{D} \delta}$ & $9.02^{\mathrm{C} \varepsilon}$ & $10.04^{\mathrm{C}}$ & $48.72^{\mathrm{B} \alpha}$ & $37.12^{\mathrm{D} \beta}$ & $30.50^{\mathrm{C} \gamma}$ & $29.68^{\mathrm{D} \delta}$ & $29.13^{\mathrm{D} \varepsilon}$ & $35.00^{\mathrm{D}}$ \\
\hline Imazethapyr 50.0 & $10.65^{\mathrm{D} \alpha}$ & $9.49^{\mathrm{DB}}$ & $9.13^{\mathrm{E \Gamma}}$ & $8.73^{\mathrm{C} \gamma}$ & $7.81^{\mathrm{D} \varepsilon}$ & $9.16^{\mathrm{D}}$ & $44.24^{\mathrm{D} \alpha}$ & $30.78^{\mathrm{E} \beta}$ & $29.39^{\mathrm{D} \gamma}$ & $28.33^{\mathrm{E} \delta}$ & $28.07^{\mathrm{E} \delta}$ & $32.16^{\mathrm{E}}$ \\
\hline Total Mean & $11.11^{\mathrm{A}}$ & $10.37^{\mathrm{B}}$ & $9.97^{\mathrm{C}}$ & $9.62^{\mathrm{D}}$ & $9.05^{\mathrm{E}}$ & & $48.30^{\mathrm{A}}$ & $38.32^{\mathrm{B}}$ & $33.69^{\mathrm{C}}$ & $31.64^{\mathrm{D}}$ & $30.32^{\mathrm{E}}$ & \\
\hline $\operatorname{LSD}(\mathrm{p}=0.05)$ & \multicolumn{6}{|c|}{0.16} & \multicolumn{6}{|c|}{0.49} \\
\hline
\end{tabular}

Same English Letter followed by mean are not significantly different with in a column and same Greek letter followed by mean are not significantly different within a row. 


\section{Conclusion}

Based on the findings of present study, it may be concluded that pendimethalin at RFD significantly enhances the mean starch, phenol content and antioxidant activity under DPPH, ABTS and FRAP assay over untreated control. Imazethapyr at $\mathrm{RFD}$, on the other hand causes an increment of protein content along with reduction in TIA level, which is more pronounced at dRFD.

\section{References}

1. Abd El-Lateef EM. Mung bean (Vigna radiata L. wilczek) yield response to late foliar application of nitrogen and potassium under different levels of phosphatic fertilization. Proceedings of the 7th Conf. 910Sep, Agron. 1996, 229-237.

2. Abd El-Sattar AM, Shaaban MM, El-masy MF. Yield potential and nutrients uptake and utilization of some vigna genotypes. Minufiya J Agric. PES 2000; 25:969986.

3. Alizadeh H, Leung DWM, Edwards Y. Changes in trypsin inhibitory activity of developing seed parts and pod of red kidney bean. Agron. 2012; 42:171-180.

4. Benzie IFF, Strain JJ. The Ferric Reducing Ability of Plasma (FRAP) as a Measure of "Antioxidant Power": The FRAP Assay. Analyt. Biochem. 1996; 239:70-76.

5. Braca A, De Tommasi N, Di-Bary L, Pizza C, Polifi M, Morelli I et al. Antioxidant principles from Bauhinia terapotensis. J Nat. Prod. 2001; 64:892-895.

6. Bradburry JH, Hammer BC. Comparative study for proteinase inhibitors in tropical root crops and survey of allelochemicals in edible aroids. J Agric. Food Chem. 1990; 38:1448-1453.

7. Bradbury JH, Holloway WD. Chemistry of tropical root crops: significancefor nutrition and agriculture in the Pacific. Australian Centre for International Agricultural Research, Canberra, Australia, 1988.

8. Elkovicz K, Souslki FW. Antinutritive factors in eleven legumes and their Air classified protein and starch fractions. J Agric. Food Sci. 1982; 47:1302.

9. Fidrianny I, Sari PI, Ruslan K. Antioxidant activities in various peel extracts of four varieties rambutan (Nepheliumlappaceum) using DPPH, FRAP assays. Int J Pharmacog Phytochem Res. 2015; 7(2):280-285.

10. Garcia LGC, Silva FA, Asquieri ER, Boas EV, Deb V, Damiani $\mathrm{C}$ et al. Bioactive compounds and antioxidant activity of jabuticaba var. Pingo de mel during its physiological development. Food Science and Technology, 2019. DOI:

11. https://doi.org/10.1590/fst. 25218

12. Ghanem EL, Abbas EL. (Improvement of mung bean growth and productivity in salinity-affected soil after seed inoculation with phosphate-dissolving bacteria. Afric. Crop Sci. Conf. Proc. 2009; 9:385-389.

13. Goodwin TW, Mercer EI. Introduction to Plant Biochemistry. 3rd Eds. Pergamon Press. 1983, 186-195.

14. Guillomen E, Pedrosa MM, Burbano C, Cuadrado C, Sanches Mde C, Muzquiz M et al. The trypsin inhibitors present in seed of different grain legume species and cultivar. Food Chem. 2008; 107:68-74

15. http:// indiastat.com. 2013

16. Kakade ML, Rackis J, McGhee JE, Puski G. Determination of Trypsin inhibitor activity of soy products: a collaborative analysis of an improved procedure. Cereal Chem. 1974; 51:378-382.
17. Larossa RA and Schloss JV. The sulfonylurea herbicide sulfometuron methyl is an extremely potent and selective inhibitor of acetolactate synthase in Salmonella typhimurium. J Biol. Chem. 1984; 259:8753-8757.

18. Lea PJ, Robinson SA and Stewart GR. The enzymology and metabolism of glutamine, glutamate and asparagines, in: P. J. Miflin, B. J Lea (Eds.). The Biochemistry of plant. Acad. Pres. 1990; 16:121-159.

19. Miflin BJ and Lea PJ. The Biochemistry of Plants. Acad. Pres. New York. 1990; 16:121159.

20. Mondy NI and Chandra S. Quality of potato tubers as affected by freezing: II. Lipid and minerals. Amer. Potato. J. 1979; 56:125-132.

21. Mosalem ME. Response of two mung bean (Vigna radiata L.) varieties to plant density. Agric. Sci. Mansoura Univ. 1999; 24:55-64.

22. NematAlla MM, Younis ME. Herbicidal effect on phenolic metabolism in maize (Zea mays L.) and soybean (Glycine $\max$ L.) seedlings. J Exp. Bot. 1995; 46:17311736.

23. Ofuya ZM, Aknidue V. The role of pulses in human nutrition. J Appl. Sci. Environ. Mgt. 2005; 9:99-104.

24. Özgen U, Mavi A, Terzi Z, Yıldırım A, Coskun M, Houghton PJ et al. Antioxidant properties of some medicinal Lamiaceae (Labiatae) species. Pharmaceut. Biol. 2006; 44:107-112

25. Parikh B, Patel VH. Total phenolic content and total antioxidant capacity of common Indian pulses and split pulses. J Food Sci Technol, 2018; 55(4):1499-1507

26. Prieto $\mathrm{P}$, Pineda M, Aguilar M. Spectrophotometric quantitation of antioxidant capacity through the formation of a phosphomolybdenum complex: Specific application to the determination of vitamin E. Anal. Biochem. 1999; 269:337-341

27. Randhir Rand Shetty K. Mungbeans processed by solidstate bioconversion improves phenolic content and functionality relevant for diabetes and ulcer management. Innov Food Sci Emerg Tech. 2007; 8:197-204

28. Rasha MA, Gibriel AY, Nagwa MHR, Abu-Salem FM, Abou-Arab EA. Influence of legume processing Treatments Individually or in combination on Their Trypsin Inhibitor and Total Phenolic Contents. Aust. J Basic Appl. Sci. 2011; 5:1322-1322

29. Ryan CA. Proteolytic enzymes and their inhibitors in plants. Ann. Rev. Plant physiol. 1973; 24:173-196.

30. Sadasivam S, Manikam A. Nitrogen analysis by Micro kjeldahl method. Bio chemical methods. new Age International (P). Ltd., Publishers. 2011, 32-35.

31. Scarponi L, NematAlla M, Martinetti L. Metolachlor in corn (Zea maize) and soybean (Glycine max): persistence and biochemical signs of stress during its detoxification. $\mathrm{J}$ Agric. Food Chem. 1992; 40:884-889.

32. Sen S, Bhattacharya A, Mazumder D, Sen H, Das AK, Pal S et al. Nutrient and antinutrient composition of cormels of colocasia esculenta var antiquorum. J Veg. Sci. 2005; 11:17-34.

33. Shi Z, Yao Y, Zhu Y, Ren G. Nutritional composition and antioxidant activity of twenty mung bean cultivars in China. The Crop Journal. 2016; 4:398-406

34. Soucek J, Skvor J, Pouckova P, Matougek J, Slavik T, Matousek J et al. Mung bean sprouts (Phaseolus aureus) nuclease and its biological and antitumor effects. Neoplasma. 2006; 53:402-409. 
35. Tomar AS. Evolution of Quizolofop ethy $14.41 \%$ EC against grassy weed in Black gram. J Crop Weed. 2011; 7:140-141.

36. Vaughn KC, Lehnen LP. Mitotic disruptor herbicides. Weed Sci. 1991; 39:450-457.

37. Vinson JA, Hap Y, Su X, Zubik L. Phenolic antioxidant quantity and quality in foods: vegetables. J Agric. Food Chem. 1998; 46:3630-3634.

38. Wang M, Li J, Rangarajan M, Shao Y, Lavoe EJ, Huang $\mathrm{T}$ and Ho C. Antioxidant phenolic compounds from sage (Salvia officinalis). J Agric. Food Chem. 1998; 46:48694873.

39. Wati RK, Theppakorn T, Benjakul Sand Rawdkuen, $\mathrm{S}$. Three phase partitioning of trypsin inhibitor from legume seeds. Process Biochemistry. 2009; 44:13071314.

40. Yao Y, Ren G, Wang JS, Chen F, Wang MF. Antidiatbetic of mung bean extracts in diabetic KK- Ay mice. J Agric Food Chem. 2008; 56:8869-8873. 